\title{
Effect of different liming levels on the biomass production and essential oil extraction yield of Cunila galioides Benth
}

\author{
Mossi, AJ. ${ }^{a *}$, Pauletti, GF. ${ }^{b}$, Rota, L. ${ }^{b}$, Echeverrigaray, S. ${ }^{b}$, \\ Barros, IBI. ${ }^{c}$, Oliveira, JV. ${ }^{a}$, Paroul, N. ${ }^{a}$ and Cansian, RL. ${ }^{a}$ \\ a Departamento de Ciências Agrárias, Universidade Regional Integrada do Alto Uruguai e das Missões - URI, \\ Av. 7 de setembro, 1621, CEP 99700-000, Erechim, RS, Brazil \\ ${ }^{b}$ Instituto de Biotecnologia, Universidade de Caxias do Sul - UCS, \\ Av. Francisco Getúlio Vargas, 1130, CEP 95070-560, Caxias do Sul, RS, Brazil \\ 'Departamento de Horticultura e Silvicultura, Universidade Federal do Rio Grande do Sul - UFRGS, \\ Av. Bento Gonçalves, 7712, CEP 90001-970, Porto Alegre, RS, Brazil \\ *e-mail: cansian@uricer.edu.br
}

Received June 22, 2011 - Accepted February 7, 2012 - Distributed November 30, 2012 (With 7 figures)

\begin{abstract}
Poejo is an aromatic and medicinal plant native to highland areas of south Brazil, in acid soils with high $\mathrm{Al}^{3+}$ concentration. The main objective of the present work was to evaluate the effect of liming on the extraction yield of essential oil of three chemotypes of poejo (Cunila galioides Benth). For this purpose, the experiments were performed in a greenhouse, using 8 -litre pots. The treatments were four dosages of limestone $\left(0,3.15,12.5\right.$, and $\left.25 \mathrm{~g} . \mathrm{L}^{-1}\right)$ and a completely random experimental design was used, with four replications and three chemotypes, set up in a $3 \times 4$ factorial arrangement. The parameters evaluated were dry weight of aerial parts, essential oil content and chemical composition of essential oil. Results showed that liming affects the biomass production, essential oil yield and chemical composition, with cross interaction verified between chemotype and limestone dosage. For the higher dosage lower biomass production, lower yield of essential oil as well as the lowest content of citral (citral chemotype) and limonene (menthene chemotype) was observed. In the ocimene chemotype, no liming influence was observed on the essential oil yield and on the content of major compounds. The dosage of 3.15 g.L. $\mathrm{L}^{-1}$ can be considered the best limestone dosage for the production of poejo for the experimental conditions evaluated.
\end{abstract}

Keywords: poejo, chemotypes, medicinal plants, essential oil.

\section{Efeito de diferentes níveis de calagem na produção de biomassa e no rendimento de extração de óleo essencial de Cunila galioides Benth}

\begin{abstract}
Resumo
O poejo é uma espécie aromática e medicinal, autóctone do sul do Brasil, encontrada em regiões de campos nativos de altitude, onde os solos se caracterizam por apresentar elevada acidez e altas concentrações de $\mathrm{Al}^{3+}$. O presente trabalho objetivou avaliar o efeito da calagem na produção de biomassa e de óleo essencial de três quimiotipos (QT) de poejo (Cunila galioides Benth.). O experimento foi conduzido em casa de vegetação utilizando-se recipientes com capacidade de oito litros. Os tratamentos consistiram de quatro dosagens de calcário dolomítico $\left(0 ; 3,15 ; 12,5 ; 25\right.$ g.L $\mathrm{L}^{-1}$ de substrato) e o delineamento experimental foi completamente casualisado, utilizando-se três quimiotipos de poejo (citral, menteno e ocimeno), quatro tratamentos e quatro repetições, em esquema fatorial $3 \times 4$. Foram avaliados o peso de matéria seca da parte aérea das plantas, o teor de óleo essencial e a composição química dos componentes majoritários presentes no óleo. Os resultados mostraram efeito da calagem na produção de biomassa, no teor e na composição química do óleo, ocorrendo efeito de interação entre quimiotipo e dosagem de calcário. Na maior dosagem, observou-se a menor produção de biomassa média, o teor de óleo essencial foi significativamente menor, assim como os componentes citral (QT-citral) e limoneno (QT-menteno). Para o quimiotipo ocimeno, as dosagens de calcário não influenciaram o teor e os componentes majoritários do óleo essencial, mas prejudicaram a produção de biomassa em doses elevadas. A calagem com 3,15 g.L $\mathrm{L}^{-1}$ de substrato, elevando o $\mathrm{pH}$ para 5,0, pode ser considerada a melhor dosagem de calcário e a mais adequada faixa de $\mathrm{pH}$ para a produção de poejo, nas condições experimentais avaliadas.
\end{abstract}

Palavras-chave: poejo, quimiotipos, plantas medicinais, óleo essencial. 


\section{Introduction}

Poejo (Cunila galioides Benth.) is an aromatic and medicinal plant belonging to Lamiaceae family (Simões et al., 1998). It comprises one of the 12 autochthonous species of South America, naturally found in highland areas of south Brazil in acid soils with high $\mathrm{Al}^{3+}$ concentration. (Coelho and Elisabetsky, 1998; Bordignon et al., 2003; Fracaro et al., 2005). Three chemotypes (CT) have been ascribed in the literature, CT-citral, CT-ocimene and CTmenthene, with a great chemical composition variability verified for different populations of Rio Grande do Sul and Santa Catarina states (Echeverrigaray et al., 2003). Medicinal and aromatic properties of poejo as well as the relatively good essential oil yields obtained, suggest the possibility of using this plant in large scale processing. For this purpose, it seems necessary the use of phytotechnical studies toward increasing the essential oil yield without affecting the properties of the product obtained.

According to Freitas et al. (2004), the biosynthesis of secondary metabolites in aromatic and medicinal plants depends on genetic, physiological and environmental factors, which makes relevant the determination of real factors that affect the concentration of bioactive compounds so as to establish its aromatic quality or therapeutical efficiency.

Liming is a common practice in agriculture aimed at enhancing field productivity. Besides reducing soil acidity and toxic effects of aluminum, a variety of changes may occur in the soil due to liming use, such as increasing the availability of some nutrients - calcium, magnesium, phosphorus and sulfur, and the reduction of some others, like boron, copper, zinc and manganese. Furthermore, an increase in microbiological activity and in the content of organic matter in soil has been attributed to liming, as well as alteration of electrochemical behaviour of colloids as a consequence of chemical modifications, hence affecting chemical and physical properties of the soil (Mello et al., 1983; Bohnen et al., 2000; Albuquerque et al., 2003).

In the Brazilian context there is a lack of qualitative and also quantitative studies concerning soil correction and its effects on essential oil production. Particularly, in Rio Grande do Sul, investigations regarding liming would be of great scientific interest, mainly with native species showing domestication potential, since spontaneously growing plants are found in acid soils. In this sense, the main objective of this work is to assess the biomass and essential oil production in three poejo chemotypes as a response of different $\mathrm{pH}$ levels obtained using different limestone dosages applied to substrate in greenhouse cultivation.

\section{Material and Methods}

\subsection{Plant material}

In this work, three chemotypes of poejo (Cunila galioides Benth.) were studied: from André da Rocha (CT-citral, AR), Santa Lúcia (CT-menthene, SL) and from Bom Jardim da Serra (CT-ocimene, BJ) populations. Plant samples (15 cm mean height, around 45-days old) used in the investigation were produced from cuttings in carbonised shell rice substrate under intermittent nebulisation.

\subsection{Growth conditions}

The experiments were carried out in greenhouse using 8 -litre plastic recipients. As substrate, soil removed from the arable shell was used, with Caxias as mapping unit and taxonomically classified as typical litholic neosol dystrophic (Streck et al., 2008). Irrigation was localised and accomplished using auto-compensating drippers, keeping the soil close to its field capacity.

The experimental planning adopted was a completely random $3 \times 4$ factorial design, with 3 populations and four levels of $\mathrm{pH}$ in the soil, comprising 4 repetitions and 3 plants for each part, totalling 144 evaluated plants. To execute the liming step and obtain the desired $\mathrm{pH}$ levels, $\mathrm{pH}$ calibration adding dolomitic limestone (PRNT 75.1\%) to $1 \mathrm{~L}$ of soil was carried out, in the following dosages: 0 , 2.5, 5.0, 7.5, 10.0, 12.5, 15.0, 17.5, 20.0, 22.5 and 25.0 g.L ${ }^{-1}$, with three repetitions. After homogeneous limestone incorporation and moistening up to field capacity, the soil was incubated for 30 days, determining the $\mathrm{pH}$ after this period affording a relationship between $\mathrm{pH}$ calibration and substrate $\left(y=4.54+0.000515 x^{3}-0.023920 x^{2}+0.375627 x\right.$, $\left.\mathrm{R}^{2}=0.96\right)$. From the calibration equation, substrate liming was prepared for the experiments with the help of a concrete mixer. Afterwards, the substrate was charged to the recipients, moistened up to the complete recipient capacity and kept covered with plastic film for 30 days. After such period, four samples of each treatment were collected and submitted to chemical analysis in the Laboratório de Análise Química do Solo of Universidade Federal do Rio Grande do Sul to determine the $\mathrm{pH}$ (Table 2).

Previous to planting, fertilisation was carried out with $\mathrm{N}=100, \mathrm{P}=400$ and $\mathrm{K}=200 \mathrm{mg} \cdot \mathrm{L}^{-1}$ of substrate, using the commercial formulation NPK 5:20:10. The experiments were conducted up to plant flowering with two harvestings: the first in the vegetative step (December) and the second in plain flowering (April). After harvesting, plants were dehydrated in a forced-air ventilation drier at $35^{\circ} \mathrm{C}$ up to constant weight, stored in plastic packages prior to the extraction of essential oils.

\subsection{Instrumentation}

The extraction of relatively volatile matter and chemical characterisation of the extract obtained regarding major components were carried out according to the procedure reported by Santos et al. (2004). Briefly, the extraction of $1 \mathrm{~g}$ of dried leaves of the three chemotypes was performed through supercritical $\mathrm{CO}_{2}$ using an HP 7680T extraction apparatus, adopting the following parameters: 30 minutes extraction time, $60^{\circ} \mathrm{C}$, pressure of $10 \mathrm{MPa}, \mathrm{CO}_{2}$ flow rate of $1.0 \mathrm{~mL} / \mathrm{min}$. Here, the extract yield is defined as the weight percentage of the oil extracted with respect to the initial charge of the raw material in the extractor (extract/ raw material, wt. (\%)). 
The extracts were analysed with a gas-chromatograph coupled to a mass spectrometric detector (HP 6890/ MSD5973), using a capillary column HP - Innovax DB-5, $\mathrm{H}_{2}(34 \mathrm{KPa})$ as carrier gas, injection in the split mode (ratio $1: 50)$, injection volume of $1 \times 10^{-9} \mathrm{~m}^{3}$ diluted in $1 \mathrm{~mL}$ of $n$-hexane. The following chromatographic conditions were used: column temperature $60{ }^{\circ} \mathrm{C}(8 \mathrm{~min}), 60-180{ }^{\circ} \mathrm{C}$ $\left(3{ }^{\circ} \mathrm{C} / \mathrm{min}\right), 180-230{ }^{\circ} \mathrm{C}\left(20^{\circ} \mathrm{C} / \mathrm{min}\right), 230{ }^{\circ} \mathrm{C}(20$ minutes $)$; interface $180{ }^{\circ} \mathrm{C}$ (Echeverrygaray et al., 2003). The identification of compounds was made by comparing the mass spectra obtained with those from the Wiley library (Wiley 275) and literature data (Echeverrigaray et al., 2003). The content of the major components of each extract is expressed as peak area percentage.

The plant parameters evaluated were dry aerial matter (DAM, g) produced in the two harvestings and the essential oil yield and its major components concentration. Experimental data were submitted to statistical variance analysis (ANOVA) and for mean values (Tukey test, 5\%), the Statistica ${ }^{\circledR} 6.0$ (Statsoft Inc.) software was used. The regression analysis and fitting procedure were performed using Microsoft Excel software.

\section{Results and Discussion}

Table 1 presents the $\mathrm{pH}$ set reached after liming for each treatment, as well as the substrate $\mathrm{pH}$ at the end of the experiments. It can be observed from this table that the $\mathrm{pH}$ reached was always lower than the set one, but with significant effect on the substrate chemical properties (Table 2). At the end of the experiment, the substrate that was not submitted to liming (original $\mathrm{pH}$ of 4.5) showed the greatest reduction in $\mathrm{pH}(4.08 \pm 0.2)$. This fact might be explained in terms of the greater $\mathrm{NH}_{4}^{+}$absorption which occurs in several acid soils, where nitrification is normally inhibited, leading to acidification of substrate due to variations in the liberation of $\mathrm{H}^{+}$or $\mathrm{OH}^{-}$, related to total ion balance absorbed, mainly in nitrogen form (Bracinni et al., 2000).

Besides correcting the soil acidity enhancing its $\mathrm{pH}$, liming also affects nutrient availability for the plants, thus increasing the availability of calcium, magnesium, phosphorus and sulfur, while reducing boron, copper, zinc and manganese (Mello et al., 1983; Bohnen et al., 2000). With the exception of phosphorus and boron, this effect was noticed in the substrate after liming. An increase in the content of organic matter of the substrate submitted to liming (Table 2) was also experimentally observed.

Regarding the liming effect on the biomass production for the three poejo populations, statistical significant differences were noted for limestone dosages applied to the substrates for a given poejo population and also among the populations, as well interaction between these two factors. For the André da Rocha population, no statistical difference was observed for DAM among the treatments, though the values found for the dosages of 3.15 and 12.5 g.L $\mathrm{L}^{-1}(\mathrm{pH}$ 5.0 and 6.1) were much higher than the others. Likewise, for the Santa Lúcia population, no significant difference was verified for the treatments, but in this case with more similar values found for the average values of DAM. The substrate dosage of 3.15 g.L. $\mathrm{L}^{-1}$ ( $\mathrm{pH}$ 5.0) afforded the best production of dry matter for the Bom Jardim da Serra population (Table 3).

Among the populations, when cultivated in high acid soil conditions without liming $(\mathrm{pH} 4.5)$, no production differences were noticed (Table 3). With the lowest limestone dosage, André da Rocha and Bom Jardim presented greater DAM values (63 g/plant) compared to the Santa Lúcia population (47 g/plant). At the dosage of $12.5 \mathrm{~g} . \mathrm{L}^{-1}(\mathrm{pH} 6.1)$, André da Rocha presented a superior value compared to the other populations, with a DAM of $59.16 \mathrm{~g} /$ plant. At the highest limestone dosage ( $\mathrm{pH}$ 6.7), André da Rocha showed the best performance (49.82 g/plant), Santa Lúcia (38.21 g/plant) and Bom Jardim (29.03 g/plant) (Table 3).

Concerning the interaction observed between liming and population factors, it should be taken into account that the natural habitat where poejo samples were collected also shows

Table 1. Amount of liming applied to soil, set and true $\mathrm{pH}$ values in the substrate used in the cultivation of poejo (C. galioides Benth.).

\begin{tabular}{cccc}
\hline $\begin{array}{c}\text { Limestone } \\
\text { dosage }\left(\mathbf{g . L} \mathbf{L}^{-1}\right)\end{array}$ & $\mathbf{p H}^{\mathbf{1}}$ & $\mathbf{p H}^{\mathbf{2}}$ & $\mathbf{p H}^{\mathbf{3}}$ \\
\hline 0 & $4.5 \pm 0.17$ & $4.5 \pm 0.14$ & $4.08 \pm 0.12$ \\
3.15 & $5.5 \pm 0.23$ & $5.0 \pm 0.21$ & $4.70 \pm 0.28$ \\
12.5 & $6.5 \pm 0.18$ & $6.1 \pm 0.14$ & $5.90 \pm 0.22$ \\
25.0 & $7.0 \pm 0.13$ & $6.7 \pm 0.15$ & $6.90 \pm 0.11$ \\
\hline
\end{tabular}

${ }^{1} \mathrm{pH}$ set on the basis of calibration curve; ${ }^{2}$ true $\mathrm{pH}$ reached after 30 liming days; ${ }^{3}$ average $\mathrm{pH}$ of each treatment after plant harvesting (220 days after liming); $\mathrm{n}=48$.

Table 2. Chemical analysis of original and submitted substrate to liming for $\mathrm{pH}$ regulation and treatment definitions.

\begin{tabular}{|c|c|c|c|c|}
\hline & \multicolumn{4}{|c|}{ Limestone dosage (g.L $\mathrm{L}^{-1}$ ) } \\
\hline & $\mathbf{0}$ & 3.15 & 12.5 & 25.0 \\
\hline Argil (m/m\%) & 33 & 32 & 34 & 34 \\
\hline Water $\mathrm{pH}$ & 4.5 & 5.0 & 6.1 & 6.7 \\
\hline SMP Index & 4.3 & 4.8 & 5.9 & 6.5 \\
\hline $\mathrm{Al}+\mathrm{H}\left(\mathrm{cmolc} \cdot \mathrm{L}^{-1}\right)$ & 16.5 & 10.5 & 3.9 & 2.3 \\
\hline CEC $\left(\mathrm{cmolc} . \mathrm{L}^{-1}\right)$ & 17.4 & 19.1 & 20.2 & 26.8 \\
\hline $\mathrm{P}\left(\mathrm{mg} \cdot \mathrm{L}^{-1}\right)$ & 3.7 & 3.1 & 3.9 & 3.2 \\
\hline $\mathrm{K}\left(\mathrm{mg} \cdot \mathrm{L}^{-1}\right)$ & 50 & 50 & 42 & 31 \\
\hline Organic matter $(\mathrm{m} / \mathrm{m} \%)$ & 4.6 & 5.2 & 6.1 & 6.0 \\
\hline $\mathrm{Al}\left(\mathrm{cmolc} . \mathrm{L}^{-1}\right)$ & 8.0 & 3.2 & 0 & 0 \\
\hline $\mathrm{Ca}\left(\mathrm{cmolc} . \mathrm{L}^{-1}\right)$ & 0.4 & 4.3 & 10.1 & 11.1 \\
\hline $\operatorname{Mg}\left(\mathrm{cmolc} . \mathrm{L}^{-1}\right)$ & 0.3 & 4.1 & 6.1 & 13.3 \\
\hline $\mathrm{S}\left(\mathrm{mg} \cdot \mathrm{L}^{-1}\right)$ & 18 & 20 & 38 & 36 \\
\hline $\mathrm{Zn}\left(\mathrm{mg} . \mathrm{L}^{-1}\right)$ & 0.7 & 0.5 & 0.1 & 0.1 \\
\hline $\mathrm{Cu}\left(\mathrm{mg} . \mathrm{L}^{-1}\right)$ & 1.2 & 0.6 & 0.1 & 0.1 \\
\hline $\mathrm{B}\left(\mathrm{mg} \cdot \mathrm{L}^{-1}\right)$ & 0.7 & 0.5 & 0.4 & 0.6 \\
\hline $\operatorname{Mn}\left(\mathrm{mg} \cdot \mathrm{L}^{-1}\right)$ & 13 & 10 & 1 & 1 \\
\hline
\end{tabular}


different ecological characteristics, mainly regarding soil type, altitude and annual average temperatures, as reported by Echeverrigaray et al. (2003). Such characteristics may lead to distinct responses for each population depending on the adaptation to the productive system. In this case, besides chemotypes, poejo populations may be also classified as ecotypes.

On the other hand, all the populations presented the common fact of acidity origin, independent of the soil type of each region, which meant that in turn, the dosage of 3.15 g.L. $\mathrm{L}^{-1}$ (pH 5.0) afforded the highest average dry aerial matter for the three poejo populations investigated, with a quadratic response to limestone application, as shown in Figure 1.

It was observed that the poejo essential oil extraction yield was affected by liming and population, with interaction verified between population and limestone dosage. The highest essential oil yield was obtained for the André da Rocha population $(1.81 \%)$, followed by Santa Lúcia (1.26\%) and Bom Jardim da Serra $(0.24 \%)$, all the mean values showing statistical difference among them (Figure 2a).

Fracaro and Echeverrigaray (2001) also found differences in the essential yield for two chemotypes of poejo, with 1.60 and $0.60 \%$ for citral and ocimeno chemotypes, respectively. It is well known that differences in the essential content for varieties and chemotypes of a given species are generally attributed to genetic factors, intrinsic to each population. The essential oil content for plants cultivated with the substrate that received the greatest milestone dosage (25 g. $\left.\mathrm{L}^{-1}\right)$ was on average 0.99 wt. (\%), lower than the other treatments, in the range of 1.11 to 1.16 wt. (\%). (Figure 2b).

Conversely, results showed the interaction between poejo population and milestone dosage. As can be seen from Figure 3, the Bom Jardim da Serra population did not present statistical difference regarding the essential oil yield as a function of limestone dosage applied to the substrate, which differs from the other populations - for

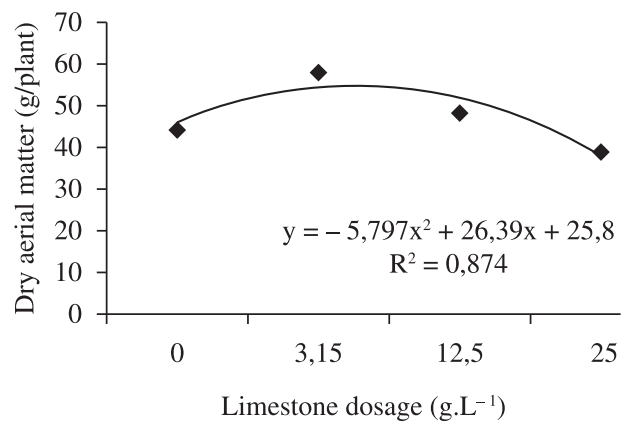

Figure 1. Effect of limestone dosage on average dry aerial matter for the three poejo (cunila galioides Benth.) populations investigated (conditions: original $\mathrm{pH}$ of 4.5).
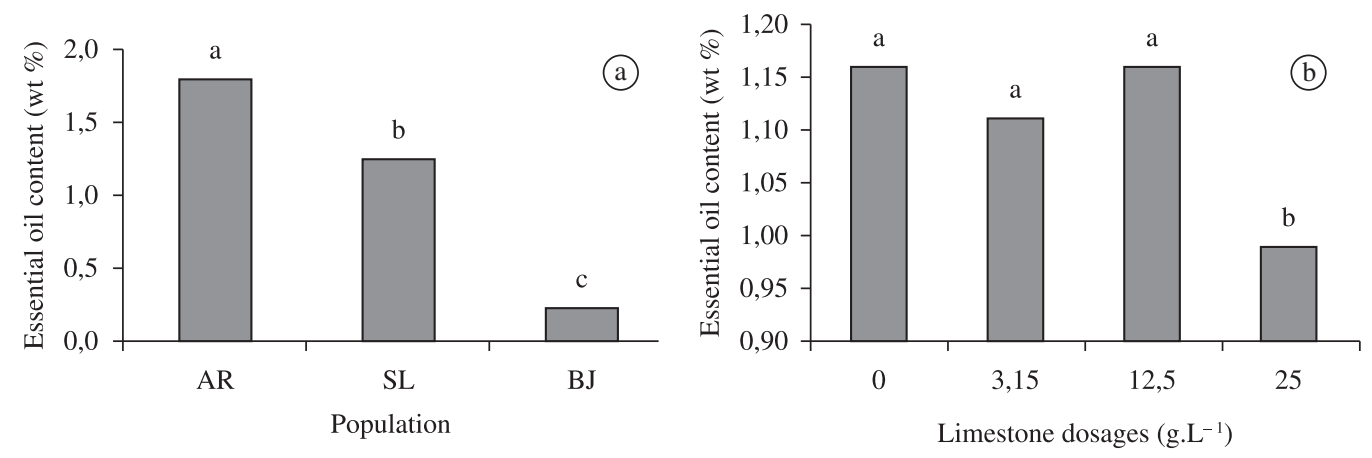

Figure 2. Essential oil yield for the three poejo populations (a) at the original $\mathrm{pH}$ (4.5) and average population values as a function of limestone dosage applied to substrate (b). Mean values followed by the same letters do not differ at 95\% (Tukey test $-\mathrm{p}<0.05)$.

Table 3. Average amount of dry aerial vegetable matter (g/plant) for the three populations of poejo (Cunila galioides Benth.) submitted to different liming levels*.

\begin{tabular}{ccccc}
\hline \multirow{2}{*}{$\begin{array}{c}\text { Limestone dosage } \\
\left(\text { g. } \mathbf{L}^{-\mathbf{1}}\right)\end{array}$} & \multicolumn{3}{c}{ Population $^{\dagger}$} & Mean \\
\cline { 2 - 4 } 0 & $\mathbf{A R}$ & $\mathbf{B J}$ & $\mathbf{S L}$ & $44.59^{\mathrm{b}}$ \\
3.15 & $48.97^{\mathrm{aA}}$ & $41.32^{\mathrm{bcA}}$ & $43.48^{\mathrm{aA}}$ & $57.99^{\mathrm{a}}$ \\
12.5 & $63.04^{\mathrm{aA}}$ & $63.31^{\mathrm{aA}}$ & $47.64^{\mathrm{aB}}$ & $48.81^{\mathrm{b}}$ \\
25.0 & $59.16^{\mathrm{aA}}$ & $44.19^{\mathrm{bB}}$ & $43.08^{\mathrm{aB}}$ & $39.02^{\mathrm{c}}$ \\
Mean & $49.82^{\mathrm{aA}}$ & $29.03^{\mathrm{cB}}$ & $38.21^{\mathrm{aAB}}$ & $43.46^{\mathrm{B}}$ \\
\hline
\end{tabular}

*different letters mean significant difference at 95\% (Tukey test $-\mathrm{p}<0.05$ ), comparison being made between lower case letters in columns with capital letters in rows. ${ }^{\dagger} \mathrm{AR}$ - André da Rocha; BJ - Bom Jardim da Serra; SL - Santa Lúcia. 
the highest milestone dosage, significant reduction in the essential oil content was observed.

Sousa et al. (2001) did not observe a pronounced effect on the biomass production and essential yield of long pepper produced in soil with and without limestone. According to these authors, it is usual to expect certain tolerance to soil acidity for plants coming from acid soils, as is the case of poejo and long pepper.

The chromatographic analysis carried out for the essential oil allowed the identification of citral (neral + geranial isomers) in the André da Rocha population, ledene and caryophyllene in Bom Jardim da Serra and limonene, borneol, 1,3,8-menthatriene and 1,5,8 p-menthatriene in Santa Lúcia as major compounds. Such compounds were employed to assess the effect of liming on the chemical composition of essential oil extracted from the three populations. These chemical compounds were also found in these populations by Echeverrigaray et al. (2003) and Fracaro et al. (2005). Statistical difference was observed only for citral and limonene present in the populations of André da Rocha and Santa Lúcia, respectively. The highest content of these compounds was noticed for plants cultivated without liming $(\mathrm{pH} 4.5)$ and at lowest limestone dosage ( $\mathrm{pH}$ 5.0). At the dosage of 12.5 g. $\mathrm{L}^{-1}$ ( $\mathrm{pH}$ 6.1), the content of citral and limonene was intermediate, whereas at the highest dosage ( $\mathrm{pH}$ 6.7), lower contents were found for these compounds, as can be observed from Figures 4 and 5. Figure 6 shows that the highest concentrations of citral and limonene were observed for the application of 3.15 g.L. $\mathrm{L}^{-1}$ of substrate (pH 5.0), 78.44\% and $15.88 \%$, respectively, resulting in a quadratic response for the liming effect.

Only a little information is available regarding the influence of nutrient levels in the soil on the biosynthesis of terpenes. However, Freitas et al. (2004) observed that an increase in $\mathrm{P}$ in the cultivation substrate of Mentha arvensis (Lamiaceae) quadratically increased the content of mentol monoterpene in the essential extract. According to Kapoor et al. (2004) and Rodrigues et al. (2004), the deficiency of $\mathrm{P}$ in the vegetable tissue of a plant may reduce the phosphorylation of mevalonic acid, which means the initial step for the synthesis of isopentenyl pyrophosphate, through the classical route of mevalonate synthesised from acetyl coenzyme A, the main precursor of monoterpenes, such as citral and limonene (Bruneton, 1991; Lange et al., 1998).

Based on the chemical analysis, the levels of $\mathrm{P}$ in the cultivation substrates of poejo might be considered much lower in the substrates without liming and limiting in the substrates that were submitted to liming (Siqueira et al., 1989), with an observed P reduction with liming (Table 2). Nevertheless, previous to planting, $\mathrm{P}$ was applied for all treatments in the dosage of $400 \mathrm{mg} . \mathrm{L}^{-1}$ in the substrates. Considering that the $\mathrm{pH}$ in the range of 6.0 to 7.0 is the best for P availability to plants (Mello et al., 1983), the hypothesis of $\mathrm{P}$ as a limiting factor does not apply and hence does not seem to be the cause of citral and limonene reduction in plants cultivated with liming at 12.5 and 25 g.L $\mathrm{L}^{-1}$

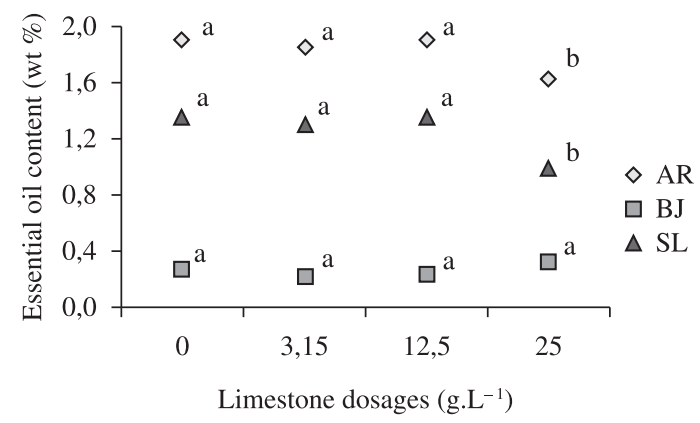

Figure 3. Effect of limestone dosage for the three populations on the essential yield (wt. (\%)). Mean values followed by the same letters do not differ at $95 \%$ (Tukey test $-\mathrm{p}<0.05)$.

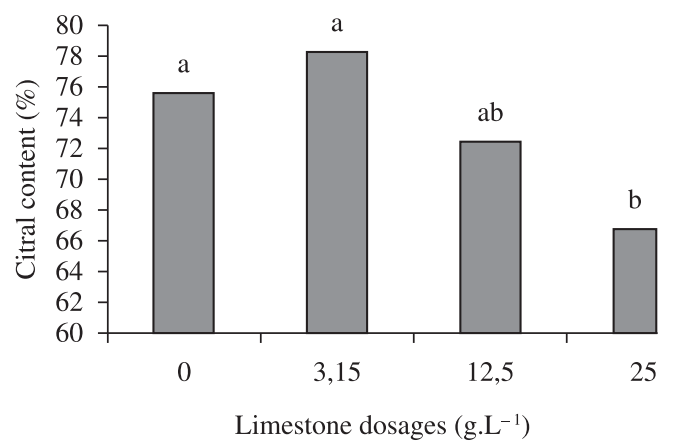

Figure 4. Citral content in André da Rocha cultivated with distinct limestone dosages applied to substrate. Mean values followed by the same letters do not differ at $95 \%$ (Tukey test $-\mathrm{p}<0.05)$.

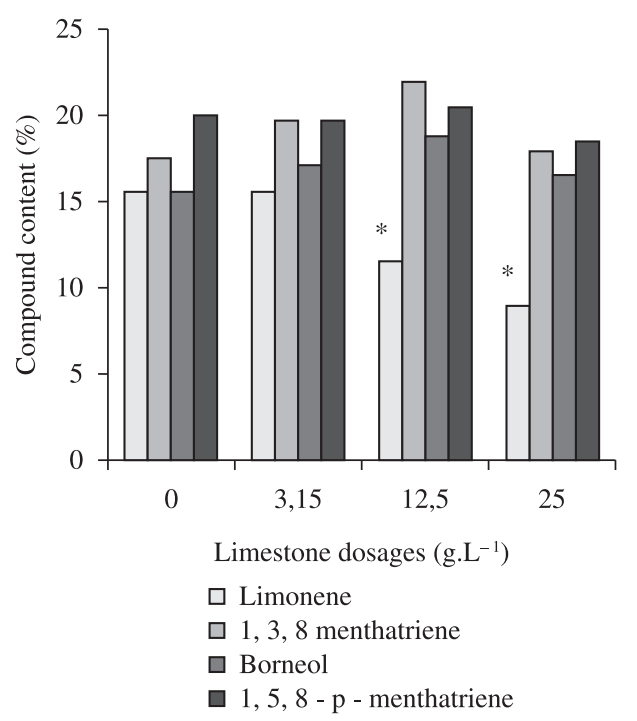

Figure 5. Content of the major compounds limonene $(\mathrm{VC}=27.78 \%), 1,3,8$ menthatriene $(\mathrm{VC}=14.88 \%)$, borneol $(\mathrm{VC}=10.28 \%)$ and $1,5,8 \mathrm{p}$-menthatriene $(\mathrm{VC}=12.58 \%)$ present in the essential oil of the Santa Lúcia population cultivated with different limestone dosages. *Significantly different for the Tukey test $(\mathrm{p}<0.05)$. 


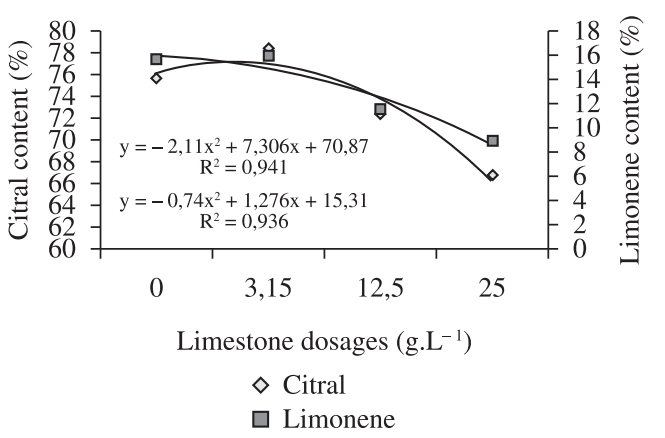

Figure 6. Citral and limonene contents in André da Rocha and Santa Lúcia populations, respectively, cultivated under different limestone dosages.

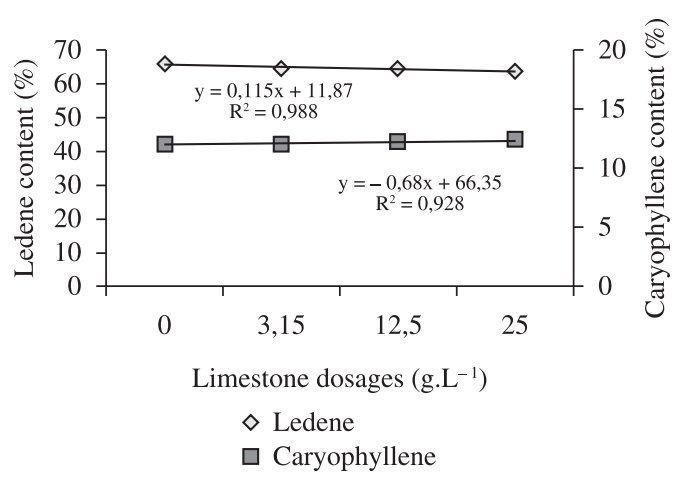

Figure 7. Content of ledene $(\mathrm{VC}=3.70 \%)$ and caryophyllene ( $\mathrm{VC}=7.99 \%$ ) present in the essential oil of Bom Jardim da Serra population cultivated with distinct limestone dosage.

substrates dosages. Therefore, more investigations should be carried out to evaluate the influence of other nutrients, besides $\mathrm{P}$, on the synthesis of terpenes, mainly those strongly affected by liming or soil $\mathrm{pH}$ like, for example, $\mathrm{Fe}$ and Mn, N, among others. For Bom Jardim da Serra population and for the other major compounds present in the essential of Santa Lúcia, liming did not affect the content of chemical components, as can be noticed from Figures 5 and 7.

\section{Conclusions}

Results obtained in this work demonstrated that liming affected significantly the biomass production for the populations studied, with the dosage of $3.15 \mathrm{~g} . \mathrm{L}^{-1}$ (pH 5.0) leading to the greatest values of dry aerial matter. Interaction effects between liming and poejo population was observed, with the Bom Jardim population most affected by limestone application to the substrate. The essential oil yield was in general negatively affected by liming, with the exception of the Bom Jardim population, which was not influenced by this factor. Major compounds of population essential oils were also affected by liming.
The content of citral in André da Rocha and limonene in Santa Lúcia populations was significantly reduced when limestone dosage of $25.0 \mathrm{~g} . \mathrm{L}^{-1}$ was applied to substrate. The limestone dosage of $3.15 \mathrm{~g} . \mathrm{L}^{-1}$, enhancing the $\mathrm{pH}$ to 5.0, promoted the best results in terms of biomass production and essential oil yield and content of major compounds.

\section{References}

ALBUQUERQUE, JA., BAYER, C., ERNANI, PR., MAFRA, AL. and FONTANA, EC., 2003. Effects of liming and phosphorus application on the structural stability of an acid soil. Revista Brasileira de Ciência do Solo, vol. 27, no. 5, p. 799-806.

BOHNEN, H., MAURER, EJ. and BISSANI, CA., 2000. Solos ácidos e solos afetados por sais. In MEURER, EJ. Fundamentos de Química do solo. Porto Alegre: Gênesis. p. 109-125.

BORDIGNON, SAL., MONTANHA, JA. and SCHENKEL, EP., 2003. Flavones and flavonones from South America species (Lamiaceae). Biochemical Systematics and Ecology, vol. 31, no. 1, p. 785-788.

BRACINNI, MCL., MARTINEZ, HEP., BRANCINNI, AL. and MENDONÇA, SM., 2000. Rhizosphere pH evaluation of coffee genotypes in response to soil aluminum toxicity. Bragantia, vol. 59 , no. 1, p. 83-88.

BRUNETON, J., 1991. Elementos de fitoquimica y de farmacognosia. Zaragoza: Acribia. 594 p.

COELHO, SGP. and ELISABETSKY, EI., 1998. Ethonobotany and anticonvulsant properties of Lamiaceae from Rio Grande do Sul (Brazil). Lamiales Newsletter, vol. 6, p. 10-13.

ECHEVERRIGARAY, S., FRACARO, F., SANTOS, AC., PAROUL, N., WASUM, R. and SERAFINI, LA., 2003. Essential oil composition of South Brazilian populations of Cunila galioides Benth. and its relation with the geographic distribution. Biochemical Systematics and Ecology, vol. 31, no. 5, p. 467-475. http://dx.doi. org/10.1016/S0305-1978(02)00175-8

FRACARO, F. and ECHEVERRIGARAY, S., 2001. Micropropagation of Cunila galioides a popular medicinal plant of south Brazil. Plant Cell, Tissue and Organ Culture, vol. 64, p.1-4. http://dx.doi.org/10.1023/A:1010626200045

FRACARO, F., ZACARIA, J. and ECHEVERRIGARAY, S., 2005. RAPD based genetic relationships between populations of three chemotypes of Cunila galioides Benth. Biochemical Systematics and Ecology, vol. 33, p. 409-417. http://dx.doi.org/10.1016/j. bse.2004.10.017

FREITAS, MSM., MARTINS, MA. and VIEIRA, IJC., 2004. Yield and quality of essential oils of Mentha arvensis in response to inoculation with arbuscular mycorrhizal fungi. Pesquisa Agropecuária Brasileira, vol. 39, no. 9, p. 887-894.

KAPOOR, R., BHOOPANDER, G. and MUKERJI, KG., 2004. Improved growth and essential oil yield and quality in Foeniculum vulgare Mill on mycorrhizal inoculation supplemented with P - fertilizer. Bioresource Technology, vol. 93, no. 3, p. 307-311. PMid:15062827. http://dx.doi.org/10.1016/j.biortech.2003.10.028

LANGE, BM., WILDUNG, MR., McCASKILL, D. and CROTEAU, R., 1998. A family of transketolases that directs isoprenoid biosynthesis via a mevalonate-independent pathway. Biochemistry, vol. 95 , p. 2100-2104. 
MELLO, FAF., BRASIL SOBRINHO, MOC., ARZOLLA, S., SILVEIRA, RI., COBRA NETTO, A. and KIEHL, JC., 1983. Fertilidade do Solo. São Paulo: Nobel. 400 p.

RODRIGUES, CR., FAQUIM, V., TREVISAN, D., PINTO, JEBP., BERTOLUCCI, SKV. and RODRIGUES, TM., 2004. Mineral nutrition, growth and essential oil content of mint in nutrient solution under different phosphorus concentrations. Horticultura Brasileira, vol. 22, no. 3, p. 573-578.

SANTOS, ACA., PAULETTI, GF., ROTA, LD., PANSERA, MR. and SERAFINI, LA., 2004. Supercritical CO2 extraction of Cunila galioides essential oil. In Proceedings of the V Brazilian Meeting on Supercritical Fluids, 2004. Florianópolis: UFSC.

SIQUEIRA, OJF., SCHERER, EE., TASSINARI, G., ANGHINONI, I., PATELLA, JF., TEDESCO, MJ., MILAN, PA., ERNANI, PR. and
WIETHÖLTER, S., 1989. Recomendação de adubação e calagem para os estados do Rio grande do Sul e Santa Catarina. 2. ed. Passo Fundo: Embrapa CNPT. 128 p.

SIMÕES, CMO., MENTZ, LA., SCHENKEL, EP., IRGANGE, BE. and STEHMANN, JR., 1998. Plantas da medicina popular no Rio Grande do Sul. 5. ed. Porto Alegre: UFRGS. 173 p.

SOUSA, MMM., LÉDO, FJS. and PIMENTEL, FA., 2001. Effect of fertilization and limestone application on production of dry matter and essential oil of long pepper. Pesquisa Agropecuária Brasileira, vol. 36, no. 3, p. 405-409.

STRECK EV., KAMPF N., DALMOLIN RSD., KLAMT E., NASCIMENTO PC., SCHNEIDER P., GIASSON E. and PINTO, L.F.S., 2008. Solos do Rio Grande do Sul. 2. ed. Porto Alegre: EMATER/RS-ASCAR, p. 222. 
